\title{
PERANAN SATUAN LALU LINTAS (SATLANTAS) DALAM EKSPEKTASI MENCEGAH PELANGGARAN LALU LINTAS DI WILAYAH POLRES KABUPATEN BARRU
}

\author{
The Role of Traffic Units (SATLANTAS) in Expectations to Prevent Traffic Violations in the Police Area \\ of Barru Regency
}

\author{
Marliany $^{1}$, Andi Rasyid Pananrangi ${ }^{2}$, Syamsul Bahri ${ }^{2}$ \\ ${ }^{1}$ Direktorat Lalu Lintas, Kepolisian Daerah Sulawesi Selatan \\ ${ }^{2}$ Program Studi Ilmu Administrasi Negara, Program Pascasarjana, Universitas Bosowa \\ Email: marlianyany122@gmail.com
}

Diterima: 04 Juli 2020

Dipublikasikan: 07 Desember 2020

\begin{abstract}
ABSTRAK
Tujuan penelitian ini adalah untuk mengetahui dan menganalisis penanggulangan dan hambatan-hambatan pelaksanaan pelanggaran lalulintas, dan menganalisis deskripsi upaya yang dilakukan polisi dalam mengurangi angka pelanggaran lalu lintas di wilayah Polres Kabupaten Barru. Metode penelitian menggunakan jenis penelitian fenomenologi dan pendekatan penelitian kualitatif. Pengumpulan data dilakukan melalui: observasi, wawancara dan dokumentasi. Informan penelitian meliputi: (1) Kanit Dikyasa, (2) Kanit Patroli, (3) Polisi Patroli, dan (3) Tokoh Masarakat. Hasil penelitian menunjukkan bahwa: (1) Implementasi Patroli Polisi dalam penanggulangan pelanggaran lalu lintas, yaitu: (a) Fasilitas patroli Polisi melengkapi patroli Polisi dalam mencegah terjadinya pelanggaran lalu lintas ternyata belum maksimal, dan (b) Intensitas patroli Polisi menunjukkan peningkatan kepedulian Polisi dalam mencegah terjadinya pelanggaran lalu lintas. (2) Faktor determinan yang menjadi hambatan Patroli Polisi dalam penanggulangan pelanggaran lalu lintas, yaitu: (a) Faktor internal pelayanan ketertiban jalan raya bekemampuan dalam. melakukan patroli untuk menanggulangi terjadinya pelanggaran lalu lintas, dan (b) Faktor eksternal pelayanan ketertiban jalan raya menunjukkan kondisi eksternal patroli polisi dalam penanggulangan pelanggaran lalu lintas kurang efektif.
\end{abstract}

Kata Kunci : Lalu Lintas, Pelanggaran, Polisi, Barru

\begin{abstract}
The aim of this study is to find out and analyze countermeasures and obstacles in handling traffic violations, and to analyze the description of the efforts made by the police in reducing the number of traffic violations in the Police Area of Barru Regency. The research method uses the type of phenomenological research and qualitative research approaches. The data collection is done through: observations, interviews and documentations. Research informants include: (1) Dikyasa Kanit. (2) Kanit Patrol, (3) Patrol Police, and (3) Community Leaders. The results showed that: (1) The implementation of Police Patrol in overcoming traffic violations, such us: (a) Police patrol facilities complementing Police patrols in preventing traffic violations were not yet optimal, and (b) The intensity of Police patrols showed an increase in Police concern in preventing traffic violations; (2) Determinant factors that become obstacles to the Police Patrol in overcoming traffic violations, such as: (a) Internal factors of road order services with internal capabilities in conducting patrols to cope with traffic violations, and (b) External factors of road order services indicate that the external conditions of police patrols in handling traffic violations are less effective.
\end{abstract}

Keywords: Police, Traffic Units, Traffic Violations, Barru

\section{PENDAHULUAN}

Berbagai perubahan senantiasa terjadi, baik secara perlahan sehingga hampir luput dari peninjauan yang biasa terjadi begitu cepat sehingga sukar untuk menyatakan dengan pasti adanya lembaga kemasyarakatan yang menetap. Demikian juga masyarakat, seiring dengan kemajuan yang dialami masyarakat dalam berbagai bidang, bertambah juga peraturan-peraturan hukum. Penambahan peraturan hukum itu tidak dapat dicegah karena masyarakat berharap dengan bertambahnya peraturan tersebut, kehidupan dan keamanan bertambah baik walaupun mungkin jumlah pelanggaran terhadap peraturanperaturan itu bertambah. (Marpaung, 2014).
Di era globalisasi saat ini manusia dituntut untuk mempunyai mobilitas yang tinggi, khususnya pada daerah perkotaan yang masyarakatnya setiap hari selalu bepergian dari satu tempat ke tempat lain untuk memenuhi kebutuhan hidupnya. Sebagian besar masyarakat menggunakan jalur darat (jalan raya) untuk melakukan mobilitasnya karena jalan raya merupakan jalur perhubungan yang murah dari pada jalur perhubungan air dan udara. Efek ini selain semakin menambah faktor kecelakaan lalu lintas, juga akan memunculkan efek domino yang semakin hari dianggap sebagai kebiasaan lalu lintas sehari-hari. Bahkan tak jarang, membuat kita menjadi tidak nyaman dalam berkendara. (Raharjo, 2014). 
Pada kenyataannya masih banyak oknum yang melalukan pelanggaran lalu lintas baik dari pihak pengguna jalan maupun penegak hukumnya sendiri. Sesuai yang terjadi dilapangan banyak pelanggaranpelanggaran lalu lintas yang dianggap kecil tapi bisa mengakibatkan gangguan besar pada ketertiban umum, kerugian, dan juga kematian. Diantaranya pelanggaran lalu lintas tersebut adalah pengguna jalan menerobos lampu lalu lintas dan para pedagang kaki lima yang menggunakan ruas jalan untuk berjualan hal tersebut sudah merupakan pelanggaran berlalu lintas. (Raharjo, 2014)

Tingkat kesadaran hukum masyarakat sebagai pemakai jalan dapat diukur dari kemampuan dan daya serap individu, serta bagaimana penerapannya di jalan raya. Manusia sebagai pemakai jalan sangat menentukan terjadinya pelanggaran-pelanggaran lalu lintas yang menimbulkan kecelakaan lalu lintas. Pasal 1 Angka 24 UU No. 22 Tahun 2009 Tentang Lalu Lintas dan Angkutan Jalan menyebutkan bahwa: "Kecelakaan Lalu Lintas adalah suatu peristiwa di jalan yang tidak diduga dan tidak disengaja melibatkan kendaraan dengan atau tanpa pengguna jalan lain yang mengakibatkan korban manusia dan/atau kerugian harta benda." Evaluasi hasil pendidikan anak usia dini: (a) belum signifikan yang dibuktikan dengan kurang penguasaan materi pelajaran oleh siswa dan kurang mampu mempraktekkannya, Penggunaan media dan sumber belajar, siswa sangat antusias dan fokus ketika guru menggunakan media ajar, Penggunaan metode pembelajaran, cara memotivasi siswa dan adanya kompetisi untuk lebih aktif, dan Penilaian hasil pembelajaran, belum efektif dan proporsional, dan, (b) Pendokumentasi hasil pembelajaran, belum memiliki Sistem Informasi Manajemen dan fasilitas Information and Communication Technology untuk proses penyelenggaraan Pendidikan (Nurhaeni et. al, 2020).

Ditambahkan pula oleh Ramdlon Nailing bahwa, "Faktor-faktor penyebab terjadinya kecelakaan adalah faktor manusia sebagai pemakai jalan (faktor utama), faktor kendaraan, faktor jalan, dan faktor keadaan atau alam". Maka dari itu pemerintah, dalam hal ini petugas hukum terutama pihak kepolisian, khususnya polisi lalu lintas, telah melakukan berbagai upaya, baik yang bersifat preventif maupun represif, untuk mencegah atau mengurangi terjadinya pelanggaran lalu lintas yang menimbulkan kecelakaan lalu lintas di jalan. (Aprilia, 2014).

Eksistensi kepolisian di Indonesia walaupun merupakan institusi peninggalan penjajah, namun secara teoritis kelahirannya bermula dari kebutuhan keinginan masyarakat untuk menciptakan situasi dan kondisi aman, tertib, tenteram dan damai dalam kehidupan sehari-hari. Kemudian berkembang sejalan dengan perkembangan dan perubahan kondisi negara dimana kepolisian menjadi kebutuhan negara sebagai alat untuk menghadapi masyarakat. Disinilah kemudian terjadi pergeseran fungsi kepolisian yang semula lahir dari keinginan masyarakat kemudian menjadi keinginan Negara, sehingga terkonsep bahwa kepolisian berada pada pihak Negara (Rahadi, 2014).

Aparat penegak hukum (polisi lalu lintas) berperan sebagai pencegah (politie toezicht) dan sebagai penindak (politie dwang) dalam fungsi politik. Di samping itu polisi lalu lintas juga melakukan fungsi regeling (misalnya, pengaturan tentang kewajiban bagi kendaraan bermotor tertentu untuk melengkapi dengan segitiga pengaman) dan fungsi bestuur khususnya dalam hal perizinan atau begunstiging (misalnya, mengeluarkan Surat Izin Mengemudi), Khususnya dalam melaksanakan patroli (Soekanto, 1989).

Satuan lalu lintas Polres Barru pada hari jumat (05/02/18) pukul 14.00 wita dalam hal ini Kasat Lantas AKP Yus Ade Elisia menggelar giat silatuhrahmi dan sosialisasi Undang-Undang. Nomor 22 Tahun 2009 Tentang Lalu Lintas dan Angkutan Jalan dengan komunitas ojek se-Kabupaten Barru sekaligus pemberian bantuan berupa helm di aula Polres Barru. Kegiatan ini merupakan kegiatan solidaritas Polres Barru khususnya Satuan Lalu Lintas kepada masyarakat untuk mempererat jalinan tali silaturahmih dan sebagai bentuk upaya untuk menertibkan dan meminimalisir laka lantas dan pelanggaran lalu lintas yang sering terjadi di wilayah hukum Polres Barru, sebagaimana yang diungkapkan oleh Kasat Lantas Barru yaitu AKP Yus Ade Elisa.

Dari hasil rekap data lalu lintas selama tahun 2018 kasus laka dan pelanggaran lalu lintas mencapai: Jumlah laka 146 kasus dengan rincian meninggal dunia 28 orang, luka berat 2 orang dan luka ringan sebanyak 116 orang dengan kerugian materi Rp.190.400.000, jumlah tilang sebanyak 1.971 pelanggar dengan vonis denda Rp.39.832.000,- jumlah teguran sebanyak 451 pelanggar.

Hal tersebut mendapat perhatian serius dari Kasat Lantas yaitu AKP Yus Ade Elisa dengan tekad meminimalisir jumlah kejadian di tahun 2018 salah satunya dengan mengadakan giat sosialisasi rutin tentang bahayanya melanggar ketika berlalu lintas. Tidak tanggung-tanggung kasat lantas menyampaikan bahwa kematian banyak terjadi saat para pengguna kendaraan di jalan raya karena dia lalai saat berkendara maupun melanggar saat berkendara. Kebiasaan buruk ini harus dibuang jauh untuk menjadi pelopor keselamatan dalam berlalu lintas, tegas Kasat Lantas saat memberikan arahan.

\section{METODE}

Penelitian dilaksanakan di wilayahPolres Kabupaten Barru, dengan melibatkan pihak polisi patroli dan pihak eksternal (masyarakat pengguna jalan raya) dengan unit analisis bagian ketertiban jalan raya pada di wilayah Polres Barru. Pendekatan penelitian yang digunakan adalah kualitatif dengan maksud untuk dapat memberikan deskripsi secara sistematis dan tuntas, faktual dan aktual terhadap obyek penelitian. Teknik analisis data kualitatif dengan menggunakan teknik analisis data yang cocok digunakan adalah teknik analisis. 


\section{HASIL DAN PEMBAHASAN}

\section{Implementasi Patroli Lalu Lintas}

a. Fasilitas Patroli Polisi

Kebijakan Light on merupakan bagian dari safety riding yang digalakkan oleh petugas kepolisian. Safety riding adalah cara berkendara yang aman demi keselamatan diri sendiri dan juga orang lain meliputi kelengkapan kendaraan (kaca spion, lampu, rem dan lain sebagainya) dan juga kelengkapan pengandara (jaket, sepatu, helm SNI, sarung tangan dan sebagainya).

Sebagai realisasi implementasi patroli lalu lintas, maka ditampilkan data tentang pelanggaran lalu lintas di Kabupaten Barru yang dapat dilihat pada Tabel 1.

Tabel 1 Onec Gas Lilin 2018 (Pelanggaran Lalu Lintas)

\begin{tabular}{llccccc}
\hline \multirow{2}{*}{ No } & \multirow{2}{*}{ Pelanggaran } & \multicolumn{2}{c}{ Tahun } & \multicolumn{2}{c}{ Trend } & Ket. \\
\cline { 3 - 7 } & & $\mathbf{2 0 1 7}$ & $\mathbf{2 0 1 8}$ & Angka & \% & \\
\hline 1 & Tilang & 858 & 796 & 63 & 7.34 & Turun \\
\hline 2 & Teguran & 1.144 & 609 & 505 & 46.77 & Turun \\
\hline Jumlah & 2.001 & 4.104 & 597 & 29.84 & Turun \\
\hline
\end{tabular}

Sumber: Satlantas Barru, 2019.

Berdasarkan Table 1. di atas menunjukkan bahwa pelanggaran lalu lintastahun 2017 dasn 2018 cukup bervariasi dan menunjukkan ada penurunan pelanggaran lalu lintas di Kabupaten Barru yaitu (1) Terkena tilang pada tahun 2017 sebanyak 858 orang, dan diberikan teguran sebanyak 1.144 orang, jadi jumlah keseluruhan adalah 2.001 orang, dan (2) Terkena tilang pada tahun 2018 sebanyak 796 orang, dan diberikan teguran sebanyak 609 orang, jadi jumlah keseluruhan adalah 4.104 orang, dan (3) Jumlah dan persentase penurunan pelanggaran dari tahun 2017 ke tahun 2018 yang terkena tilang sebanyak 63 orang atau 7.34 persen, sedangkan Jumlah dan persentase penurunan pelanggaran dari tahun 2017 ke tahun 2018 yang terkena teguran sebanyak 505 orang atau 46.77 persen,.

\section{b. Intensitas Patroli Polisi}

Dari tabel diatas dapat terlihat bahwa semenjak kebijakan ini dikeluarkan, tahun 2016 dan 2017 memang menurun jika dibandingkan tahun 2015, yaitu dari 1629 kejadian pada tahun 2015 menjadi 1463 kejadian di tahun 2016 dan 1264 kejadian di tahun 2017 namun di tahun 2018 kembali meningkat menjadi 1420 kejadian. Pada kasus kecelakaan kategori SIM pengendara dan korban sedikit berbeda. Kasus kecelakaan kategori pelaku dan korban SIM C atau sepeda motor pada tahun 2015 sebanyak 466 kejadian (pelaku) dan 739 kejadian (korban). Pada tahun 2016 mengalami kenaikan yang cukup signifikan yaitu sebanyak 471 kejadian (pelaku) dan 1070 kejadian (korban), namun pada tahun 2017 dan 2018 mengalami penurunan, yaitu 636 kejadian (pelaku) 363 kejadian (korban) dan 352 kejadian (pelaku) 297 kejadian (korban).
Menurut Ipda AT, terlepas dari kontroversi yang ada di masyarakat, angka kecelakaan di Kabupaten Barru cenderung menurun senjak diberlakukannya Light on ini, khususnya yang melibatkan kendaraan roda dua. Pihak Satlantas Polres Barru mengaku bahwa memang kebijakan Light on di Barru memang belum berjalan sesuai dengan yang diharapkan, namun mereka sampai saat ini tetap berupaya melakukan sosialisasi terus menerus agar kebijakan Light on ini berjalan sesuai dengan tujuan yang diharapkan dan masyarakat juga semakin sadar akan pentingnya keselamatan berkendara.

\section{Faktor Determinan Patroli Polisi}

\section{a. Faktor Internal Patroli Polisi}

Secara internal, menurut Burhan gaji aparat kepolisian, khususnya polisi lalu lintas masih sangat rendah. Hanya berkisar 2-3 juta. Hal ini menurut beliau menjadi salah satu faktor yang membuat beberapa oknum polisi lalu lintas memberikan peluang untuk terjadinya penyuapan terkait kasus pelanggaran lalu lintas.

Polisi masyarakat sebagai strategi Polri dalam menyelenggarakan tugasnya merupakan suatu langkah penting dan mendasar untuk mengubah paradigma konvensional menjadi paradigma kontemporer yang lebih menekankan pada kemitraan, pemecahan masalah, upaya pencegahan, dan peningkatan kesadaran hukum masyarakat. Dalam konsep polmas, polisi sebagai katalisator yang mendukung masyarakat untuk membangun dan menjaga keamanan di lingkungannya. Konsep ini bukan untuk melawan kejahatan, tetapi untuk mencari dan melenyapkan penyebab kejahatan di suatu masyarakat tertentu.

Negara-negara modern dan demokratis pada saat ini menerapkan sistem Polmas, sebagai alternatif pemolisiannya, yang dilaksanakan secara proaktif dalam memecahkan masalah dan berorientasi pada masyarakat dalam memelihara keteraturan sosial. Polmas dilakukan dengan strategi polisi bersama masyarakat mengidentifikasi dan menyelesaikan berbagai masalah di tengah masyarakat, senantiasa mengurangi ketakutan masyarakat akan gangguan kriminalitas, dan berusahan meningkatkan kesadaran hukum masyarakat.

\section{b. Faktor Eksternal Patroli Polisi}

Faktor eksternal yang mempengaruhi kinerja polisi dalam menegakkan dan menerapkan kesadaran hukum adalah masyarakat. Menurut beliau terkadang oknumoknum tertentu yang selalu melakukan pelanggaran hukum pada umumnya, pelanggaran lalu lintas pada khususnya, merupakan penghambat dalam menerapkan kesadaran hukum di masyarakat.

Artinya memang tidak ada kesadaran hukum dari oknum pelanggar tersebut. Hal ini tentu mempengaruhi persepsi anggota masyarakat lainnya, sehingga sangat 
dimungkinkan terjadinya pelanggaran hukum yang lebih banyak.

Selain masyarakat secara umum, stakeholder yang berperan penting di dalam masyarakat juga harus melakukan pengawasan terhadap perilaku masyarakat di lingkungannya dan membantu pihak kepolisian dalam menanamkan nilai-nilai kesadaran hukum terhadap anggota masyarakatnya.

\section{Upaya Penanggulangan Penanganan Lalu Lintas}

Pada fokus ini menggunakan pendekatan model Implementasi George C. Edward. Menurut Edward keberhasilan suatu implementasi kebijakan dipengaruhi oleh empat variabel, yaitu komunikasi, sumber daya, disposisi, dan struktur birokrasi. Lebih jelasnya dapat diperhatikan penjelasan berikut:

\section{a. Komunikasi}

Implementasi suatu kebijakan dapat mencapai keberhasilan apabila maksud dan tujuan dari kebijakan tersebut dapat di komunikasikan dengan baik kepada seluruh implementor dan juga kepada kelompok sasaran. Dalam implementasi kebijakan Light on ini komunikasi telah dilakukan mulai dari tahap sosialisasi hingga sekarang. Tahap sosialisasi dimulai sejak UU No.22 Tahun 2009 diberlakukan hingga saat ini. Sosialisasi tidak hanya dilakukan oleh pihak Implementor kepada kelompok sasaran saja, namun sosialisasi juga dilakukan dengan oleh penyelenggara, dalam hal ini adalah pemerintah. Setelah peraturan ini disahkan oleh pemerintah dan DPR kemudian diturunkan atau didelegasikan kepada pihak pelaksana yaitu Kepolisian RI.

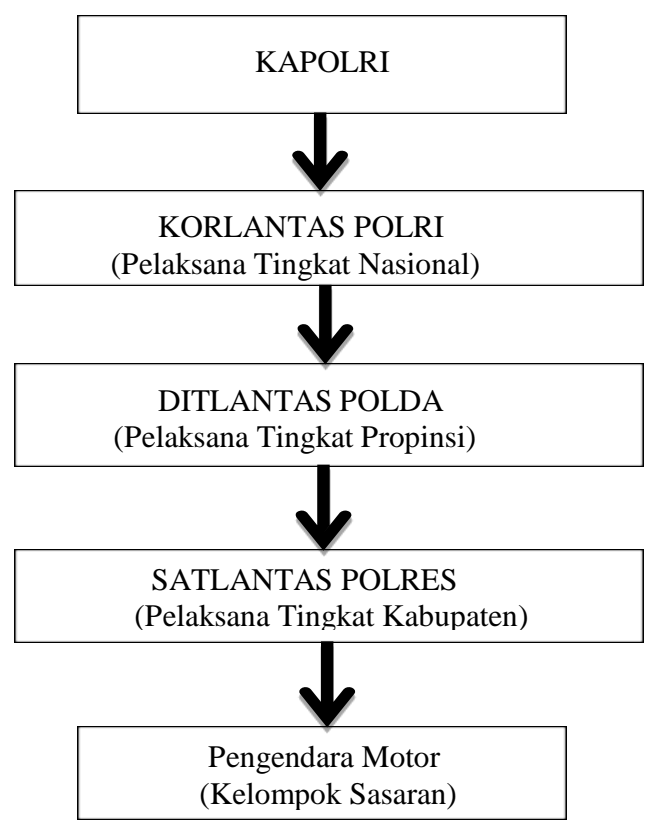

Gambar 1 Alur Sosilalisasi Kebijakan Light on
Meskipun sudah tertuang di dalam UU No.22 tahun 2009 pasal 107 ayat 2, namun pihak implementor juga mendapatkan perintah khusus dari Kapolri melalui surat telegram. Surat telegram biasanya berisi perintah dari pimpinan kepada bawahannya meliputi SOP dan penjelasan-penjelasan khusus mengenai perintah yang didelegasikan. Jika ada perubahan perintah dari atasan, biasanya juga diberitahukan melalui surat telegram. Perintah Implementasi Kebijakan Light on dari Kapolri tersebut, oleh Dirlantas Polda Sul-Sel kemudian dituangkan dalam bentuk Surat Telegram, salah satunya adalah Surat Telegram Dirlantas Polda Sul-Sel No:ST/63/IX/2011 tanggal 30 September 2011.

Seletah petugas lalin dari kepolisian melakukan sosialisasi cara berkedara dengan baik dan benar, maka pemerintah meluncurkan Undang-Undang Nomor 11 tahun 2008 tentang Informasi dan Teknologi Elektronik. Tilang Elektronik atau Pelanggaran digitalisasi yang dinamakan dengan E-tilang adalah denda yang dikenakan oleh penegak hukum yaitu Polisi kepada pengguna / pemakai jalan yang melanggar peraturan di Kabupaten Barru.

Sesuai hasil penelitian tentang upaya penanggulangan pelanggran lalu lintas, maka peneliti menyimpulkan temuan penelitian bahwa:

1) Alur kebijakan Undang-Undang Nomor 11 tahun 2008 tentang Informasi dan Teknologi Elektronik dan UU nomor 22 Tahun 2009 tentang Lalu Lintas dan Angkutan Jalan disosialisasikan sekitar awal tahun 2010 setelah Undang-Undang tersebut dikeluarkan.

2) Cara bayar e-tilang di Kabupaten Barru bisa melalui kejaksaan. Adapun cara cek E-Tilang di Kabupaten Barru dengan mengunjungi website polres Kabupaten Barru lalu cari menu tilang atau situs pihak ketiga seperti cektilang.com ketik nomor ETilang/nomor Blanko / nomor BRIVA anda lalu klik Cek untuk mengetahui berapa besar denda dan biaya yang harus dibayarkan.

3) Selanjutnya cara cek denda tilang Kejaksaan Kabupaten Barru, ada 2 cara yaitu melalui website atau pun melalui handphone (HP). kalau melalui website. buka situs resmi kejaksaan negeri pemerintah Kabupaten Barru lalu klik menu tilang dan ketikkan nomor resi nya. kalau melalui Handphone (HP), silahkan kunjungi playstore dan download aplikasi resmi dari pemerintah atau kejaksaan negeri. Bisa juga dengan cara membuka Sistem Informasi Penelusuran Perkara (SIPP) kemudian anda ketikkan nomor kendaraaan dan Nomor E-Tilang anda. untuk pembayaran denda tilang dan pengambilan barang bukti, anda cukup datang ke kantor kejaksaan Negeri Kabupaten Barru. 
Apabila nomor tilang anda sudah di putus atau belum oleh pengadilan negeri Kabupaten Barru. dan

4) Jika tidak ada dalam daftar sesuai dengan tanggal putusan yang di tentukan oleh pengadilan negeri Kabupaten Barru, maka anda bisa langsung menghubungi pihak terkait (Pihak kepolisian atau DLLAJ).

b. Sumberdaya Patroli Lain

Sumber daya merupakan faktor penting dalam sebuah implementasi kebijakan. Pencapaian tujuan sebuah kebijakan tidak akan berjalan maksimal apabila tidak didukung dengan sumber daya yang memadahi baik berupa sumber daya manusia ataupun sumberdaya finansial. Awalnya peneliti sempat menduga bahwa implementor atau pelaksana kebijakan Light on ini adalah pihak kepolisian dan Dinas Perhubungan, karena kedua instansi tersebut sama-sama mempunyai wewenang dalam bidang lau lintas,

Saat dimintai keterangan mengenai sumber daya finansial ini pihak Satlantas Polres Barru menyatakan bahwa anggaran memang ada namun hanya terbatas untuk operasional sosialisai kebijakan yang sifatnya penyuluhan saja. Jumlahnya tidak disebutkan, namun pihak Satlantas menyatakan bahwa anggaran yang berasal dari pemerintah tersebut telah mencukupi. Sedangkan untuk pengadaan media sosialisasi seperti spanduk, baliho, iklan radio dan sebagainya, pihak Satlantas juga tidak merasa kesulitan karena pengadaan media sosialisasi biasanya dilakukan dengan bekerjasama dengan pihak sponsor atau istilahnya rekanan. Bekerja sama dengan pihak sponsor tersebut menguntungkan bagi kedua belah pihak, karena di satu sisi Satlantas Polres Barru sebagai implementor sangat dibantu dengan adanya media sosialisasi yang dibuat oleh pihak sponsor tanpa mengeluarkan biaya, di sisi lain pihak sponsor juga mendapatkan keuntungan karena dengan memberikan media sosialisai Light on secara mereka juga dapat mengiklankan produknya kepada para konsumen secara gratis. Pihak sponsor yang dimaksud disini diantaranya adalah Dinas Perhubungan Kabupaten Barru, Dealler Suzuki Indojaya Motor, dan Radio Persatuan FM.

\section{c. Disposisi Kepolisian}

Karakteristik implementor akan sangat berpengaruh terhadap implementasi kebijakan. Hal ini berkaitan dengan sikap implementor yang mendukung atau menolak adanya kebijakan Light on di Barru. Sebagai pelayan masyarakat, Satlantas Polres Barru telah menunjukkan komitmennya dalam menciptakan suasana aman, tertib dan lancar selama berlalu lintas di wilayah Kabupaten Barru. Komitmen Satlantas Polres Barru tersebut tercermin dalam kesungguhannya melaksanakan kebijakan Light on ini. Terbukti dengan berbagai upaya yang dilakukan untuk mensosialisasikan kebijakan tersebut kepada kelompok sasaran, mulai dari penyuluhan kepada kelompok masyarakat terorganisir, pemasangan media sosialisasi (Spanduk, Baliho dan lain sebagainya) dijalan-jalan utama di Kabupaten Barru, hingga turun langsung ke jalan untuk mengingatkan secara langsung pada para pengendara sepeda motor untuk menyalakan lampu pada siang hari.

Disposisi merujuk pada kerakteristik yang menempel erat pada diri implementor kebijakan. Karakter yang penting dimiliki oleh implementor kebijakan adalah kejujuran, komitmen, dan demokratis. Kejujuran mengarahkan implementor untuk tetap berada di dalam arah yang telah digariskan dalam guideline kebijakan tersebut. Komitmen akan membawa implementor semakin antusias dalam melaksanakan tahap-tahap program secara konsisten. Sedangkan demokratis akan meningkatkan kesan baik implementor dan kebijakan dihadapan kelompok sasaran.

Komitmen implementor ditunjukan pada keseriusan Satlantas Polres Barru dalam mengemban tugas dan kewajiban yang diberikan oleh pimpinan. Keseriusan ini terlihat saat Satlantas Polres Barru melakukan berbagai upaya untuk mendukung keberhasilan kebijakan tersebut, sebagai contohnya adalah keseriusan dalam hal sosialisasi. Sejak diberlakukannya kebijakan tersebut hingga sekarang, Satlantas polres Barru tidak hentihentinya melakukan sosialisasi kepada kelompok sasaran walaupun sempat menemui berbagai kendala. Mulai dari penyuluhan kepada masyarakat, pemasangan baliho, spanduk yang bertuliskan himbauan agar pengandara menyalakan lampu di siang hari hingga turun langsung ke jalan untuk memberikan himbauan kepada para pengendara sepeda motor.

Sedangkan wujud demokratias yang ada pada diri implementor nantara lain ditunjukan dengan adanya operasi simpatik. Operasi simpatik ini meliputi pemberian stiker, dan bunga kepada para pengguna jalan yang dilakukan dalam rangka mensosialisasikan program kepada kelompuk sasaran. Operasi simpatik ini biasanya dipimpin langsung oleh kanit Dikyasa Polres Barru. Tujuan operasi simpatik ini adalah untuk meningkatkan kesan baik implementor dan kebijakan dihadapan kelompok sasaran supaya implementasi kebijakan dapat berjalan sesuai dengan tujuan yang diharapkan.

\section{d. Struktur Birokrasi}

Dalam sebuah implementasi kebijakan, tentu tidak akan pernah lepas dari Standart Operating Procedures (SOP). SOP merupakan sebuah pedoman yang digunakan oleh implementor dalam melaksanakan tugas-tugas mereka. Menurut pihak implementor, SOP yang termasuk tidak berbelit-belit dan mudah dipahami, sehingga pihak implementor juga tidak kesulitan dalam melaksanakan kebijakan tersebut. Ditambah lagi Light on ini bukanlah 
hal yang rumit untuk sosialisasikan kepada kelompok sasaran. Kebijakan ini hanya mengharuskan para pengendara sepeda motor untuk menyalakan lampu utamanya saat berkendara pada siang hari.

Jika dilihat dari struktur organisasi, Satlantas Polres Barru sudah memiliki struktur yang jelas dan tidak terlalu rumit, hierarkinya pun juga tidak terlalu panjang, sehingga dalam hal penyampaian informasi dari atasan kepada bawahan tidak memakan waktu yang lama. Namun di satu sisi Satlantas Polres Barru mempunyai karakteristik struktur organisai yang kaku dan sangat tegas. Sama dengan organisasi kepolisian lainnya, Satlantas Polres Barru juga menganut sistem hierarki yang kaku. Dalam organisasi polisi atau militer menganut prinsip bahwa seorang bawahan harus patuh terhadap atasan, jadi pemimpin mempunyai andil yang besar dalam pengambilan keputusan.

Kepolisian selalu melakukan penindakan yakni dengan memberikan tilang terhadap pelaku yang melakukan pelanggaran lalu lintas. Baik pelanggaran yang terjadi pada lalu lintas sehari-hari maupun saat pelasanakan penertiban yakni rasia kendaraan bermotor. Dimana biasanya polisi meminta kelengkapan surat yakni STNK dan SIM yang akan diperiksa, bila tidak bisa menunjukan maka dikena sanksi berupa tilang. Selain diberi bukti tilang dapat juga terjadi penyitaan STNK atau SIM pengendara, penyitaan tersebut sementara guna barang bukti telah melanggar lalu lintas. SIM disita yakni sebagai barang bukti yang dapat diambil kembali saat sudah mengikuti persidangan. Dalam persidangan tersebut akan dikenakan sanksi denda sesuai peraturan.

Jadi kesalahan prosedur di atas tidak bisa kita salahkan pihak kepolisian namun juga masyarakat sebagai pengendara kendaraan bermotor harus mengetahui dan patuh kepada hukum, yakni bila melanggar maka akan dikenakan sanksi sesuai hukum dan prosedurnya. Bukannya dengan cara bermusyawarah yang merupakan pelanggaran suap. Data kepolisian wilayah resor Barru dalam kurun waktu 2014 sampai 2018 jumlah penyitaan SIM mencapai 12.881, yang paling banyak yakni pada tahun 2015 yang mencapai 4.079 dan yang tidak memiliki/ tidak bisa menunjukan SIM yakni 17.647 dan STNK disita berjumlah 679. Jumlah yang cukup mendasar terjadinya pelanggaran dan kecelakaan lalu lintas karena keterampilan dalam berkemudi kendaraan belum cukup lancar, sebagaimana Data penyitaan SIM dan STNK pada tahun 2014 sampai 2018 disatuan lalu lintas polres Barru

\section{KESIMPULAN DAN SARAN}

Kesimpulan hasil penelitian ini bahwa satuan Lalu Lintas Kepolisian resort Barru mengadakan patroli disetiap hari kerja (senin-jumat) guna menanggulangi pelanggaran-pelanggaran yang sering terjadi di
Kabupaten Barru khususnya didaerah-daerah yang rawan pelanggaran, kecelakaan dan kemacetan dengan menggunakan bentuk patroli motor atau dengan mengendarai mobil atau patroli bermobil. Dalam melakukan patroli, Satlantas Polres Barru masih mengalami beberapa hambatan yang kadang membuat patroli tersebut kurang maksimal dan kurang efektif. Upaya yang dilakukan oleh Satlantas Polres Barru untuk mengurangi angka pelanggaran lalu lintas di Kabupaten Barru yaitu pelaksanaan sosialisasi Undang-undang Nomor 22 Tahun 2009 Tentang Lalu Lintas dan Angkutan Jalan dan program 1 desa 1 polisi.

Saran dalama penelitian ini adalah salah satu hal yang dapat mencegah peningkatan bahkan mengurangi angka pelanggaran yang dilakukan oleh para pelajar yakni merutinkan sosialisasi kepada msyarakat agar masyarakat paham tentang lalu lintas dan dampak yang timbul akibat dari pelanggaran tersebut.

\section{DAFTAR PUSTAKA}

Aprilia, Kiki Riski. 2014, Peranan Polantas Dalam Penertiban Pelanggaran Lalu Lintas Yang Berpotensi Menyebabkan Kecelakaan Lalu Lintas Di Polresta Padang, Jurnal Penelitian, Fakultas Hukum Universitas Tamansiswa Padang.

Edward III, George C. 1980, Implementing Public Policy, Congressional Quarterly Press, Washington.

Kiki Riski Aprilia, 2014, Peranan Polantas Dalam Penertiban Pelanggaran Lalu Lintas Yang Berpotensi Menyebabkan Kecelakaan Lalu Lintas Di Polresta Padang, Jurnal Penelitian, Fakultas Hukum Universitas Tamansiswa Padang,

Marpaung, Leden. 2014. Asas-Teori-Praktik Hukum Pidana, Sinar Grafika, Jakarta.

Nurhaeni, N., Pananrangi, A. R., \& Bahri, S. (2020). Efektivitas Pendidikan Lalu Lintas Pada Anak Usia Dini Di Kabupaten Kepulauan Selayar. Jurnal Paradigma Administrasi Negara, 2(1), 48-53.

Rahardi, Pudi. 2014, Hukum Kepolisian: Kemandirian Profesionalisme dan Reformasi POLRI, Laksbang Grafika, Surabaya,

Raharjo, Rinto. 2014. Tertib Berlalu Lintas, Shafa Media, Yogyakarta.

Soekanto, Soerjono. 1989. Suatu Tinjauan Sosiologi Hukum Terhadap Masalah - Masalah Sosial, Bandung : Citra Aditya Bakti.

Undang-Undang Nomor 22 Tahun 2009 Tentang Lalu Lintas dan Angkutan Jalan.

Undang Nomor 11 tahun 2008 tentang Informasi dan Teknologi Elektronik 